\title{
Dichotomy Concept of Urang Asa And Urang Dagang In Tambo Minangkabau: A Semiological Interpretation
}

\author{
Silvia Rosa ${ }^{1}$, Hendro $^{2}$ \\ \{sylvie_rosha@ymail.com\} \\ Andalas University, Faculty of Humanities ${ }^{1}$, Andalas University, Postgraduate Program in Literature ${ }^{2}$
}

\begin{abstract}
Tambo Minangkabau stores the thoughts, ethics, and aesthetics that govern people's lives. However, as a work of literary historiography, all ideas are wrapped in diction and symbolic language styles that need to be interpreted more seriously and in detail. This article aims to explain the symbolic meaning contained behind the concept of Urang Asa and Urang Dagang Dagang in one of the episodes Tambo Minangkabau. Roland Barthes's semiologic theory is applied to explain the heap of symbols that wrap around the discourse about Urang Asa and Urang Dagang. The method used in this study is an interpretive descriptive method of analyzing data sourced from words, phrases, sentences contained in Minangkabau Tambo. The results showed that Tambo resented the different rights and obligations between the groups of Urang Asa and Urang Dagang in the order of life of Minangkabau people. Semiologically, this episode indicates the ideology of materialism also influences a person's position in possession of communal relative's property in Minangkabau society. As it turns out, classical literature also holds that ideology.
\end{abstract}

Keywords: Urang Asa, Urang Dagang, Tambo Minangkabau, semiology

\section{Introduction}

Literary texts contain signs that must be pursued by the use of them. The pursuit of the sign, as Culler stated, must be done through a critique activity [1]. The activities of literary criticism of Minangkabau Tambo, so far have not done much. Meanwhile, Tambo Minangkabau, as a classic literary work contains many signs related to the history, culture, and civilization of Minangkabau people. There have been few previous studies that have tried to discuss this material object, among them Tsuyoshi Kato who attempted to explain the aspects of change and sustainability to the matrilineal system in Minangkabau reflected in Tambo Minangkabau [2]; and philology studies of several variants of the text of Tambo Minangkabau [3]. A recent study conducted by Rosa stated that the two episodes of Tambo Minangkabau served as a strategy tricking the Minangkabau defeat from the invasion of military forces coming from the opposite ground, as symbolized by the episode Teka-Teki Kayu Tataran and episode Teki-Teki Unggas [4]. Besides, there are no studies focused on discussing Minangkabau Tambo as the object of literary criticism.

This article is present to complement the lack of information related to Tambo Minangkabau. Barthes's semiology approach is used as a theoretical perspective in pursuit of inclusion. Tambo Minangkabau is a storehouse of knowledge about the history of the 
Minangkabau people [4]. Tambo Minangkabau, as a work of classical literature, is a sign. Therefore, the inclusion of Barthes' semiology perspective was important in this study. Semiology is a science related to signs. The sign implies a connection between something concrete and an abstract one. The sign also represents the relationship between "form" and "meaning".

The relationship between "sound image" and "concept". The connection can be an arbitrator or motivated sign formed by two parts that overlap such as the upper and lower faces (recto and verso sides) of a piece of paper. When one side or surface is cut, it also cuts the other side or surface. The two sides that are enclosed in each other are markers and signage. The signifier is what can be done in-depth, simple, and coherent (epistemological criteria) by linguistics without going through an extralinguistic premise and can be sensed by the five senses. A marker is a mediator; the substance of the marker is always material (sound, object, imaginary). On the other hand, the sign is a series of aspects of linguistic phenomena that cannot be described in depth without going through the extralinguistic premise process. Signified is not an "object", but a mental representation of an "object" [5].

\section{Research Methods}

This research uses qualitative methods. Data collection is done through literature studies. The main data of the research is sourced from Tambo Minangkabau. Several episodes build Minangkabau Tambo. One of the episodes talks about the concept of Urang Asa (original person) and Urang Dagang (migrant). This episode became a topic of discussion in this article. The data analysis unit in this study is words, sentences, phrases, paragraphs, and discourses that tell about Urang Asa and Urang Dagang in Minangkabau Tambo.

The narrative contained in this episode is first translated into Indonesian language because the data unit is presented in the local language, namely Minangkabau Language. Data analysis techniques are performed by applying Roland Barthes' semiology theory with a focus on lexical analysis. Lexia is in the state of words, sentences, speech, and also discourse [6]. Lexia helps to read the text differently [7]. Lexia can also help necessary literacy skills for students in reading text [8]; even now to be one of the programs in-text learning [9].

\section{Results and Discussion}

Urang Asa and Urang Dagang episodes tell the story of each individual's position and rights in Minangkabau customary constellations. This episode consists of several units of events. The episode about Urang Asa consists of twenty-one units of event. While the episode Urang Dagang consists of sixteen event units. Urang Asa is a term for the community group that first hit a residential area. On the other hand, Urang Dagang is a term for a group that came later to inhabit a country. Table 1 below presents the Lexia event units and groups found in the episode Urang Asa. 
Table 1. Event unit and Lexia about Urang Asa

\begin{tabular}{|c|c|c|c|}
\hline Page & Narrative & Event unit & Lexia \\
\hline 20 & $\begin{array}{l}\text { Bermula Sultan Maharadja Diradja berlajar menuju } \\
\text { kepulau Djawi Alkibri pulau Pertja Andalas namanya, jaitu } \\
\text { dengan suatu perahu, serta pengiringnja seekor Andjing } \\
\text { Mu'lim, seekor Kutjing Siam dan seekor Harimau Tjampo } \\
\text { dan seekor Kambing Hutan. Jang dinamakan Harimau, } \\
\text { Andjing dan Kambing bukannja binatang, tetapi ini gelaran } \\
\text { pangkat-pangkat pengiring Radja itu. Hanja kelakuannja } \\
\text { seperti binatang-binatang itu. }\end{array}$ & $\begin{array}{l}\text { The arrival of sultan } \\
\text { Maharadja Diraja's } \\
\text { entourage on a large } \\
\text { boat. }\end{array}$ & 1 \\
\hline 21 & $\begin{array}{l}\text { Maka mufakatlah jang ada dalam perahu itu semuanja, } \\
\text { akan memperbaiki perahu itu, karena takut akan titah } \\
\text { daulat jang Dipertuan, dan dimulailah oleh Tjati Bilang } \\
\text { Pandai memperbaiki perahu itu. }\end{array}$ & $\begin{array}{l}\text { The event of repairing } \\
\text { a damaged boat }\end{array}$ & 2 \\
\hline \multirow[t]{2}{*}{21} & \multirow{2}{*}{$\begin{array}{l}\text { Maka tiada berapa lama antaranja, beranaklah sekalian } \\
\text { binatang itu, Andjing, Kutjing, Harimau dan Kambing. } \\
\text { Maka semuanja diambil oleh Radja akan mendjadi } \\
\text { anaknja. Setelah berapa lamanja mereka diam di puntjak } \\
\text { Gunung Merapi itu maka sekalian anaknja itu sampailah } \\
\text { baliq, dan dinikahkannja anak itu semua dengan tukang } \\
\text { jang memperbaiki perahu itu, karena dahulu dijandjikan } \\
\text { oleh Sulthan Mahardja Diradja akan mengambil djadi } \\
\text { menantunja. }\end{array}$} & $\begin{array}{l}\text { The group settled on } \\
\text { the summit of Mount } \\
\text { Merapi and } \\
\text { proliferated. }\end{array}$ & 3 \\
\hline & & $\begin{array}{l}\text { The children, born to } \\
\text { members of the } \\
\text { boating troupe, were } \\
\text { raised as children by } \\
\text { the Sultan Maharadja } \\
\text { Diradja. }\end{array}$ & 4 \\
\hline \multirow[t]{3}{*}{22} & \multirow{3}{*}{$\begin{array}{l}\text { Setelah berapa lama antaranja, maka laut itu menjentak } \\
\text { surut atau bertambah kering djuga, maka datanglah dari } \\
\text { atas puntjak Gunung Merapi seperti awan mendjurai } \\
\text { rupanja jaitu berdjurai empat, dan bersuara di dalamnja, } \\
\text { sedjurai keranah Tanah Datar alamat tinggal di situ seorang } \\
\text { anak daulat jang dipertuan. }\end{array}$} & The tide is receding. & 5 \\
\hline & & $\begin{array}{l}\text { Sacred cloud events } \\
\text { that have four jurai }\end{array}$ & 6 \\
\hline & & $\begin{array}{l}\text { One jurai lives in } \\
\text { Tanah Datar }\end{array}$ & 7 \\
\hline 22 & $\begin{array}{l}\text { Sedjurai lagi keranah Lima Puluh alamat akan tinggal pula } \\
\text { seorang daulat jang dipertuan disana. }\end{array}$ & One jurai lives in fifty & 8 \\
\hline 22 & $\begin{array}{l}\text { Sedjurai keluak Agam alamat tinggal pula seorang anak } \\
\text { daulat jang dipertuan disana. }\end{array}$ & $\begin{array}{l}\text { One jurai lives in } \\
\text { Agam }\end{array}$ & 9 \\
\hline 22 & Dan yang sedjurai lagi ke Tandjung Lasi. & $\begin{array}{l}\text { One more jurai to } \\
\text { Tanjung Lasi }\end{array}$ & 10 \\
\hline 22 & $\begin{array}{l}\text { Adapun jang tinggal pada luak ranah Tanah Datar ialah } \\
\text { anak daulat jang dipertuan, dan seorang keluak Agam ialah } \\
\text { anak Harimau. }\end{array}$ & $\begin{array}{l}\text { The Daulat Yang } \\
\text { Dipertuan's son lives } \\
\text { in Tanah Datar }\end{array}$ & 11 \\
\hline 22 & $\begin{array}{l}\text { Dan seorang keluak ranah Lima Puluh ialah anak } \\
\text { Kambing, dan seorang ke Tandjung Lasi ialah anak } \\
\text { Kutjing. }\end{array}$ & $\begin{array}{l}\text { A man goes into the } \\
\text { realm of Limo Puluh. }\end{array}$ & 12 \\
\hline \multirow[t]{2}{*}{22} & \multirow{2}{*}{$\begin{array}{l}\text { Adapun mula-mula bertempat daulat jang dipertuan } \\
\text { kepada Langun di Bida namanja, kemudian tempat itu } \\
\text { dididami oleh ninik Ketumanggungan djo ninik Perpatih } \\
\text { nan Sabatang bersumpah jang bahasa buatan teguh djandji } \\
\text { erat dengan Ketumanggungan dan Perpatih nan Sabatang } \\
\text { iaitu bernama Nik 'Ali namanja, iaitu orang jang } \\
\text { bersumpah satir dengan Alimun dan sekalian Djihin jang } \\
\text { menghuni tempat disana beragih hutan tinggi dan rendah } \\
\text { kaju rembajan dan lurus lari' rembajan samak dan gurun, } \\
\text { di sanalah daulat jang dipertuan itu tinggal. }\end{array}$} & $\begin{array}{l}\text { Daulat Yang } \\
\text { Dipertuan stopped by } \\
\text { and settled in Lagundi } \\
\text { Bida. }\end{array}$ & 13 \\
\hline & & $\begin{array}{l}\text { The oath of allegiance } \\
\text { of Datuk } \\
\text { Ketumanggungan and } \\
\text { Datuk Perpatih Nan } \\
\text { Sebatang with Nik } \\
\text { "Ali. }\end{array}$ & 14 \\
\hline
\end{tabular}




\begin{tabular}{|c|c|c|c|}
\hline & & $\begin{array}{l}\text { Nik A'li was the first } \\
\text { to swear by Alimun } \\
\text { and Jin to inhabit the } \\
\text { new territory. }\end{array}$ & 15 \\
\hline \multirow[t]{3}{*}{22} & \multirow{3}{*}{$\begin{array}{l}\text { Lama kelamaan karena telah berkembang djuga manusia } \\
\text { itu banjak anak beranak tjutju bertjutju pada tempat itu, } \\
\text { sehingga kesudahannja tempat itu menjadi negeri. Maka } \\
\text { pada satu ketika mufakatlah segala isi negeri itu. Seorang } \\
\text { bergelar Dt. Maradjo Basa di Padang Pandjang, dan } \\
\text { seorang bergelar Dt. Bandaro Kajo di Pariangan Padang } \\
\text { Pandjang. Maka orang itulah mula-mula memakai gadang } \\
\text { kebesaran di negeri jang dua itu pada masa dahulunja. } \\
\text { Kemudian mufakatlah isi negeri semuanja akan } \\
\text { mendirikan Balai Balerong Pandjang guna bermufakat. } \\
\text { Dan jang dipertuan menitahkan kepada Tjati Bilang } \\
\text { Pandai. }\end{array}$} & $\begin{array}{l}\text { The establishment of } \\
\text { land called Pariangan. }\end{array}$ & 16 \\
\hline & & $\begin{array}{l}\text { The granting of } \\
\text { customary titles. } \\
\text { To two indigenous } \\
\text { leaders, Datuk } \\
\text { Maradjo Basa and } \\
\text { Datuk Bandaro Kayo. }\end{array}$ & 17 \\
\hline & & $\begin{array}{l}\text { Establishment of } \\
\text { Balerong Panjang } \\
\text { Hall as a place of } \\
\text { worship. }\end{array}$ & 18 \\
\hline 24 & $\begin{array}{l}\text { Maka bertitahlah daulat jang dipertuan kepada Tjati Bilang } \\
\text { Pandai akan mentjari tanah daratan tempat kediaman rakjat } \\
\text { jang sudah kembang itu. }\end{array}$ & $\begin{array}{l}\text { King ruled Tjati } \\
\text { Bilang Pandai to seek } \\
\text { land in the mainland }\end{array}$ & 19 \\
\hline \multirow[t]{2}{*}{24} & \multirow{2}{*}{$\begin{array}{l}\text { Sesudah itu turunlah Radja itu ke Bumi Setangkai namanja } \\
\text { jaitu tudjuh orang perempuan dan kemudian menurut pula } \\
\text { delapan perempuan dengan bersama laki-laki dan disuruh } \\
\text { diamlah oleh daulat jang dipertuan orang-orang bumi } \\
\text { Setangkai itu, dan barulah daulat jang dipertuan itu pulang } \\
\text { kembali kepada negeri Pariangan Padang pandjang. }\end{array}$} & $\begin{array}{l}\text { The new area visited } \\
\text { by the King named } \\
\text { Bumi Setangkai. }\end{array}$ & 20 \\
\hline & & $\begin{array}{l}\text { The group also } \\
\text { brought with them, } \\
\text { fifteen women and } \\
\text { men. }\end{array}$ & 21 \\
\hline
\end{tabular}

Twenty-one units of events are displayed in table 1 while representing twenty-one units of meaning. Lexia is a unit of meaning that can be found in the state of words, groups of words and also in the form of sentences. Lexia guides us to understand the codes contained in the Tambo text. There are five codes included in a text, as described by Barthes, namely the hermeneutic code, the semic code, the symbolic code, the proaretic code, and the gnomic code [6]; [11]. These five codes are derived from Lexia attached to each code. The installation of Lexia into each of these codes guides us to define the text in depth. The following Table.2 describes the meanings found behind the lexicon that has been displayed in Table.1 before.

Table 2. Five-Code Analysis of Urang Asa Episode

\begin{tabular}{llll}
\hline & Lexia & Event unit & Meaning \\
\hline & 1 & $\begin{array}{l}\text { The arrival of Sultan Maharadja } \\
\text { Diraja's entourage on a large boat. }\end{array}$ & The origin of the arrival of ancestors. \\
\cline { 2 - 5 } $\begin{array}{l}\text { Hermeneut } \\
\text { ic code }\end{array}$ & 4 & $\begin{array}{l}\text { The event of repairing a damaged } \\
\text { boat }\end{array}$ & $\begin{array}{l}\text { The origin of the heirloom is down to } \\
\text { the niece }\end{array}$ \\
\cline { 2 - 5 } & 6 & $\begin{array}{l}\text { Sacred cloud events that have four } \\
\text { jurai }\end{array}$ & $\begin{array}{l}\text { Opening of new settlements around } \\
\text { the slopes of Merapi } \\
\text { Aevelopment of society in } \\
\text { Minangkabau. }\end{array}$ \\
\hline
\end{tabular}




\begin{tabular}{|c|c|c|c|}
\hline & 14 & $\begin{array}{l}\text { The oath of allegiance of Datuk } \\
\text { Ketumanggungan and Datuk } \\
\text { Perpatih Nan Sebatang with Nik "Ali }\end{array}$ & $\begin{array}{l}\text { Magical efforts made by Datuk } \\
\text { Ketumanggungan and Datuk Perpatih } \\
\text { Nan Sebatang in opening new land. }\end{array}$ \\
\hline \multirow{5}{*}{ Semic code } & 7 & One jurai lives in Tanah Datar & $\begin{array}{l}\text { The early man who entered luhak } \\
\text { Tanah Datar }\end{array}$ \\
\hline & 8 & One jurai lives in Limo Puluh. & $\begin{array}{l}\text { The early man who entered Luhak } \\
\text { Limo Puluh }\end{array}$ \\
\hline & 9 & One jurai lives in Agam & $\begin{array}{l}\text { The early man who entered Luhak } \\
\text { Agam }\end{array}$ \\
\hline & 10 & One more jurai to Tanjung Lasi & $\begin{array}{l}\text { Early humans who entered Tanjung } \\
\text { Lasi }\end{array}$ \\
\hline & 12 & One went into the Limo Puluh. & Another went to luhak Limo Puluh \\
\hline \multirow{6}{*}{$\begin{array}{l}\text { Symbolic } \\
\text { code }\end{array}$} & 11 & $\begin{array}{l}\text { The King's son dwells in Tanah } \\
\text { Datar }\end{array}$ & The King's son lives in Tanah Datar \\
\hline & 13 & $\begin{array}{l}\text { Daulat Yang Dipertuan stopped by } \\
\text { and settled in Lagundi Bida. }\end{array}$ & $\begin{array}{l}\text { The inauguration of Lagundi Nan } \\
\text { Baselo as the home region. }\end{array}$ \\
\hline & 14 & $\begin{array}{l}\text { The magical efforts of Datuk } \\
\text { Ketumanggungan and Datuk } \\
\text { Perpatih Nan Sebatang in opening } \\
\text { new land. }\end{array}$ & $\begin{array}{l}\text { The magical efforts of Datuk } \\
\text { Ketumanggungan and Datuk Perpatih } \\
\text { Nan Sebatang in opening new land. }\end{array}$ \\
\hline & 23 & $\begin{array}{l}\text { Migration of females and males who } \\
\text { will continue the descent. }\end{array}$ & $\begin{array}{l}\text { Migration of females and males who } \\
\text { will continue the descent. }\end{array}$ \\
\hline & & Indo Djalito gives birth to a son. & Start enforcing patriarchy \\
\hline & 24 & The sovereign who died. & Devolution of the throne \\
\hline \multirow{3}{*}{$\begin{array}{l}\text { Proaretic } \\
\text { code }\end{array}$} & 16 & $\begin{array}{l}\text { The establishment of a country } \\
\text { called Pariangan. }\end{array}$ & $\begin{array}{llll}\begin{array}{l}\text { The origins of Nagari in } \\
\text { Minangkabau }\end{array} & & & \\
\end{array}$ \\
\hline & 17 & $\begin{array}{l}\text { The granting of customary titles to } \\
\text { two indigenous leaders, Datuk } \\
\text { Maradjo Basa and Datuk Bandaro } \\
\text { Kayo. }\end{array}$ & $\begin{array}{l}\text { Formulation of pusako (material } \\
\text { collective) title treasures to men }\end{array}$ \\
\hline & 18 & $\begin{array}{l}\text { The establishment of Balerong } \\
\text { Panjang Hall as a place of worship. }\end{array}$ & Create a customary place of worship. \\
\hline \multirow{3}{*}{$\begin{array}{l}\text { Gnomic } \\
\text { Code }\end{array}$} & 19 & $\begin{array}{l}\text { King ruled Tjati Bilang Pandai to } \\
\text { seek land in the mainland }\end{array}$ & Finding new land for settlements \\
\hline & 20 & $\begin{array}{l}\text { The new area visited by the King } \\
\text { named Bumi Setangkai. }\end{array}$ & $\begin{array}{l}\text { Expansion of territory to Bumi } \\
\text { Setangkai }\end{array}$ \\
\hline & 21 & $\begin{array}{l}\text { The group also brought with them, } \\
\text { fifteen women and men. }\end{array}$ & Early groups of ancestors \\
\hline
\end{tabular}

The twenty-one Lexia described in table 2, connotatively, refers to the meaning of the Urang Asa (original people) group that opened up residential and agricultural land for the first time. This group is also referred to as the ancestors of the Minangkabau. They came sailing from the opposite side of the land when the sea rose. This sea-level rise event is thought to occur when the event melts ice at the North Pole. The group opened up farmland. The group claims that they are entitled to the process of devolution of residential land and farmland to their later descendants. Thus, it can be interpreted that those who own and have the right to bequeath residential land and agricultural land are Urang Asa group in Minangkabau. 
In addition to identifying the event units in the episode Urang Asa, we also identified the event units contained in the episode Urang Dagang. Furthermore, the following table 2 presents the event units and Lexia groups found in the episode Urang Dagang.

Table 3. Event unit and lexia on Urang Dagang

\begin{tabular}{|c|c|c|c|}
\hline No & Narrative & Event unit & Lexia \\
\hline \multirow[t]{3}{*}{58} & \multirow{3}{*}{$\begin{array}{l}\text { Maka datanglah nakhoda perahu itu akan } \\
\text { menghabisi peperangan itu dengan bertakok kaju } \\
\text { kenegeri Lima Kaum Dua Belas Koto dan mereka } \\
\text { menepat di Bukit Batu Patah membawa sebuah } \\
\text { Kaju Tataran Naga namanja. }\end{array}$} & $\begin{array}{l}\text { The arrival of the boat skipper } \\
\text { to fight to Limo Kaum Dua } \\
\text { Belas Koto. }\end{array}$ & 1 \\
\hline & & $\begin{array}{l}\text { The group lived in Bukit Batu } \\
\text { Patah. }\end{array}$ & 2 \\
\hline & & $\begin{array}{l}\text { The troupe brought the Kayu } \\
\text { Tataran Naga to the puzzle. }\end{array}$ & 3 \\
\hline 58 & $\begin{array}{l}\text { Maka berkatalah Nahkoda itu kepada Dt. Suri } \\
\text { Diradjo dimuka segala orang seisi negeri Laras nan } \\
\text { dua itu jaitu Laras Koto Pilaing dan Laras Bodi } \\
\text { Tjaniago. }\end{array}$ & $\begin{array}{l}\text { The skipper spoke to Datuk } \\
\text { Suri Dirajo who was witnessed } \\
\text { by the entire community in } \\
\text { Lareh Nan Duo. }\end{array}$ & 4 \\
\hline 58 & $\begin{array}{l}\text { Maka sahut nahkoda itu: Hendak mendjalani Pulau } \\
\text { Pertja ini, karena orang-orangnja adalah orang } \\
\text { tjerdik pandai semuanja lagi laut bitjaranja sebab } \\
\text { itulah kami datang kemari. }\end{array}$ & $\begin{array}{l}\text { The skipper came to Perca } \\
\text { Island because he was attracted } \\
\text { to his community, who were } \\
\text { bright and articulate. }\end{array}$ & 5 \\
\hline \multirow[t]{3}{*}{61} & \multirow{3}{*}{$\begin{array}{l}\text { Sesudah itu datang pula beberapa perahu dari laut } \\
\text { membawa kerbau pandjang tanduk, maka menepat } \\
\text { di di Bukit Gombak, maka didjadikannja Sungai } \\
\text { Emas dan perahu itupun lalu kepada Bukit Patah. }\end{array}$} & $\begin{array}{l}\text { The arrival of several boats } \\
\text { carrying long buffalo horns. }\end{array}$ & 6 \\
\hline & & $\begin{array}{l}\text { The group stopped by Bukit } \\
\text { Gombak. }\end{array}$ & 7 \\
\hline & & $\begin{array}{l}\text { The group continued to Bukit } \\
\text { Batu Patah. }\end{array}$ & 8 \\
\hline 65 & $\begin{array}{l}\text { Adapun perahu jang datang dari laut bertakok kaju } \\
\text { dan mengadu kerbau itu, bukanja mentjari } \\
\text { perniagaan serta mentjari kemenangan harta, hanja } \\
\text { perahu itu berisi balatentara dari keradjaan Madjo } \\
\text { Pahit ditanah Djawa. }\end{array}$ & $\begin{array}{l}\text { The group of boats carrying The } \\
\text { Kayu Tataran and the boat } \\
\text { company having the buffalo } \\
\text { also contained soldiers from } \\
\text { Majapahit kingdom }\end{array}$ & 9 \\
\hline \multirow[t]{2}{*}{69} & \multirow[t]{2}{*}{$\begin{array}{l}\text { Oleh karena laras nan dua mengaku tunduk, maka } \\
\text { diterimalah oleh Radja Waditiawarman tadi serta } \\
\text { Radja itu diangkat menjadi Radja di Minangkabau } \\
\text { menurut Batu Basurat di Pagarujung pada tahun } \\
1340\end{array}$} & $\begin{array}{l}\text { People who adhere to the Lareh } \\
\text { Nan Duo system receive } \\
\text { Widitiawarman as Radja } \\
\text { Minangkabau. }\end{array}$ & 10 \\
\hline & & $\begin{array}{l}\text { Confessions of Widitiawarman } \\
\text { as King of Minangkabau is } \\
\text { listed in the inscription Batu } \\
\text { Bersurat in Pagaruyung in } \\
1340 .\end{array}$ & 11 \\
\hline 70 & $\begin{array}{l}\text { Maka kawinlah Radja itu di Minangkabau dengan } \\
\text { Putri Djahilan Adik atau anak oleh Dt. Suri Diradjo. }\end{array}$ & $\begin{array}{l}\text { Raja Widitiawarman married } \\
\text { Puti Djahilan (son of Datuk } \\
\text { Suri Diradjo). }\end{array}$ & 12 \\
\hline 70 & $\begin{array}{l}\text { Maka berapa lama antaranja hamilah putri Djahilan } \\
\text { istri Radja itu dan setelah tjukup bulanja lahirlah } \\
\text { anaknja. }\end{array}$ & Puti Djahilan is pregnant. & 13 \\
\hline 74 & $\begin{array}{l}\text { Maka pergilah Dt. Bidjajo ke tempat Radja } \\
\text { Sarulangun akan bertanja, kalau ada Dt. } \\
\text { Katumanggungan singgah di tempat itu. }\end{array}$ & $\begin{array}{l}\text { Dt Bidjajo traces the journey of } \\
\text { Datuk Ketumanggungan to } \\
\text { Sarolangun. }\end{array}$ & 14 \\
\hline
\end{tabular}


74 Sesudah orang-orang itu berdjalan kembali ke Datuk Bidjajo was married to 15 Minangkabau maka dikawinkanlah Dt. Bidjajo oleh Saribanilai. orang pondok itu dengan anaknja jang bernama Saribanilai.

75 Sesudah itu pindahlah dia kepada satu tempat jang tidak berapa djauh dari situ dan didirikanlah rumah di tempat itu seperti bentuk rumah Minangkabau.

Datuk Bidjajo and Saribanilai 16
moved somewhere and set up a
house similar to the
Minangkabau house.

Source: [10].

Furthermore, in table 3 has been described as sixteen Lexia contained in the episode Urang Dagang. The twenty-one Lexia is grouped into five codes to reinforce the meanings stored behind the scattered Lexia. The following table 4 describes Lexia's discussion of the five codes.

Table 4. Five-code analysis of the Urang Dagang episode

\begin{tabular}{|c|c|c|c|}
\hline & Lexia & Event unit & Meaning \\
\hline \multirow{3}{*}{$\begin{array}{l}\text { Hermene } \\
\text { utic code }\end{array}$} & 3 & $\begin{array}{l}\text { The troupe brought the Kayu Tataran } \\
\text { Naga to the puzzle. }\end{array}$ & $\begin{array}{l}\text { Symbols of disguise and } \\
\text { phishing. }\end{array}$ \\
\hline & 5 & $\begin{array}{l}\text { The skipper came to Perca Island } \\
\text { because he was attracted to their } \\
\text { community, who were smart and } \\
\text { articulate. }\end{array}$ & Ruse \\
\hline & 4 & $\begin{array}{l}\text { The skipper spoke to Datuk Suri Dirajo } \\
\text { who was witnessed by the entire } \\
\text { community in Lareh Nan Duo. }\end{array}$ & $\begin{array}{l}\text { Introduction and take the } \\
\text { hearts of the people }\end{array}$ \\
\hline \multirow{2}{*}{$\begin{array}{l}\text { Semic } \\
\text { code }\end{array}$} & 9 & $\begin{array}{l}\text { The group of boats carrying Kayu } \\
\text { Tataran and the boat company having } \\
\text { the buffalo also contained soldiers from } \\
\text { Majapahit kingdom }\end{array}$ & $\begin{array}{l}\text { The initial act of war from } \\
\text { Majapahit. }\end{array}$ \\
\hline & 11 & $\begin{array}{l}\text { Widitiawarman's recognition as King of } \\
\text { Minangkabau is listed in the inscription } \\
\text { Batu Bersurat in Pagaruyung in } 1340 \text {. }\end{array}$ & $\begin{array}{l}\text { The group of Urang Dagang } \\
\text { are given the recognition of } \\
\text { power. }\end{array}$ \\
\hline \multirow{6}{*}{$\begin{array}{l}\text { Symbolic } \\
\text { code }\end{array}$} & 6 & $\begin{array}{l}\text { The arrival of several boats carrying long } \\
\text { buffalo horns. }\end{array}$ & $\begin{array}{l}\text { The influx of outsiders into } \\
\text { Minangkabau land. }\end{array}$ \\
\hline & 2 & The group lived in Bukit Batu Patah & $\begin{array}{l}\text { Expansion of territory into } \\
\text { Minangkabau land. }\end{array}$ \\
\hline & 10 & $\begin{array}{l}\text { The people who adhered to the Lareh } \\
\text { Nan Duo system received } \\
\text { Widitiawarman as Raja Minangkabau. }\end{array}$ & Confessions of submission \\
\hline & 15 & Datuk Bidjajo married Saribanilai. & Consensus \\
\hline & 12 & $\begin{array}{l}\text { Raja Widitiawarman married Puti } \\
\text { Djahilan (son of Datuk Suri Diradjo). }\end{array}$ & Peace \\
\hline & 16 & $\begin{array}{l}\text { Datuk Bidjajo and Saribanilai moved } \\
\text { somewhere and set up a house similar to } \\
\text { the Minangkabau house. }\end{array}$ & $\begin{array}{l}\text { The beginning } \\
\text { Minangkabau migration }\end{array}$ \\
\hline \multirow{2}{*}{$\begin{array}{l}\text { Proaretic } \\
\text { code }\end{array}$} & 1 & $\begin{array}{l}\text { The arrival of the boat skipper to fight to } \\
\text { the Limo Kaum Dua Belas Koto. }\end{array}$ & $\begin{array}{l}\text { Expansion of power into } \\
\text { Minangkabau land }\end{array}$ \\
\hline & 7 & The group stopped by Bukit Gombak. & $\begin{array}{l}\text { Expansion of power into } \\
\text { Minangkabau land }\end{array}$ \\
\hline
\end{tabular}




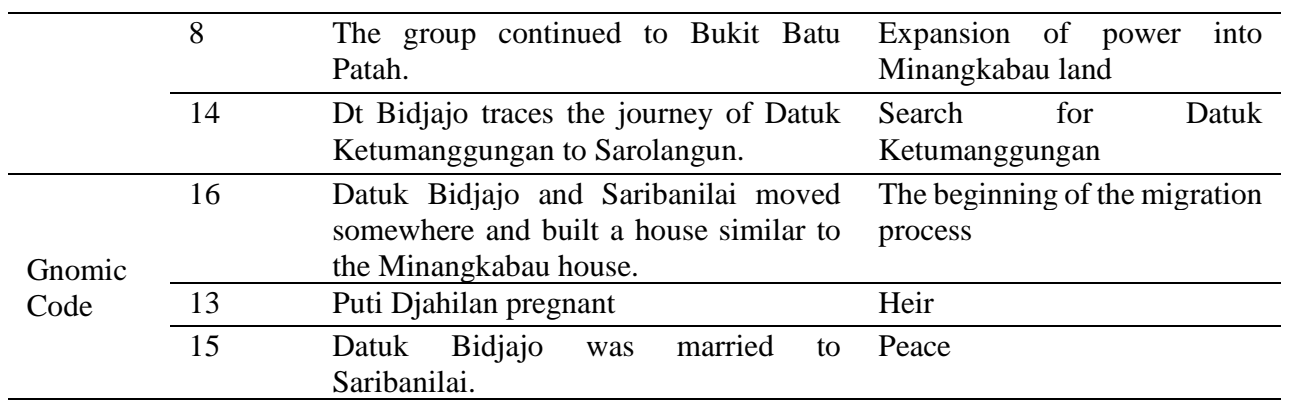

Based on the analysis of the five codes presented in table 4, semiotic can be interpreted that Urang Dagang is a group of people who came later to Minangkabau land and then occupied the area in several ways. Some of the ways that happen are through military invasion, trade, and through activation in various other sectors of the economy. The first army invasion was carried out by a group of people coming from across the country. Tambo Minangkabau quotation states as follows: "Adapun perahu jang datang dari laut bertakok kaju dan mengadu kerbau itu, bukanja mentjari perniagaan serta mentjari kemenangan harta, hanja perahu itu berisi balatentara dari keradjaan Madjo Pahit di tanah Djawa “. [10]. This quote expressly states that the boating party that came from the opposite land did not come to trade and or seek wealth to Minangkabau, but rather to attack and subdue the Minangkabau. They carried a large army in their big boat. The Minangkabau's did not have military forces in their government system.

The Minangkabau chose a leader who was referred to as King instead of in the capacity of being the leader of a monarchy and equipped with a military fleet. However, the King known in Minangkabau society was an indigenous leader. The rules and rules used are social and cultural rules that apply in Minangkabau. Of course, when the invasion of the Majapahit kingdom came, Datuk Ketumanggungan as the leader of the Minangkabau people at that time was afraid and unprepared to see the behaviour of the party that came from Majapahit. Datuk Ketumanggungan's concern for the danger and threat has forced the Datuk Ketumanggungan to declare submission. Datuk Suri Dirajo was sent by Datuk Ketumanggungan to express request to the coming party. The offer is represented in Lexia 10, which reads as follows, "The people who adhere to the Lareh Nan Duo system receive Widitiawarman as Radja Minangkabau" [10].

The confession of submission allegedly occurred after the arrival of the boating group for the second time. In one of the articles, it was stated that the Minangkabau people performed two puzzle games on two occasions of the arrival of the group from the opposite ground. The appearance of the first group was greeted with a game of Kayu Tataran puzzles, and the Minangkabau people managed to win the puzzle. The boating group felt ashamed, then left Minangkabau land. The arrival of the boating group was the second time, greeted by Minangkabau people with a game of Teka-teki Unggas. Minangkabau people again won this Teka-teki unggas game. The boating troupe was humiliated by their defeat in the bet. They were forced to leave Minangkabau land and give all the possessions and gold they brought to the Minangkabau people who witnessed their collapse in the betting puzzle game [4].

Thus, it can be guessed, the confession of submission of the Minangkabau people, as stated in Lexia 10 quoted from page 69, occurred after the arrival of the second boating group. The military invasion and power exercised by Urang Dagang's entourage were able to break the skills and intelligence of Minangkabau people in speaking and playing sense. At the same time, this situation is proof that the royal system in Minangkabau society is just a slogan. The kingdom in Minangkabau was not armed with military weapons. This condition is a factor that justifies 
that the most significant power in Minangkabau society is not the military field, but rather in the field of debate and tongue-in-cheek using words. While words, according to Barthes, is talking about the world directly [12]. However, even though the Urang Asa group was forced to surrender to the Urang Dagang, they did not favour dividing material property to the Urang Dagang group. The implication of this policy, Urang Dagang, has no right to devolution. Thus, it can be interpreted that the right to bequeath and obtain the devolution of residential land and agricultural land is Urang Asa group. On the contrary, such rights are not possible to be owned and enjoyed by the Urang Dagang group.

\section{Conclusion}

As it turns out, two social, cultural groups are institutionalized in Minangkabau society. Urang Asa group and Urang Dagang group. The group of Urang Asa is a group that is in the region for the first time. They became the ancestors of the Minangkabau people. They become owners of collective heritage, in the form of agricultural land, plantations, forestry, and fisheries. They have the right to bequeath communal property matrilineally to the next generation within the scope of matrilineal kinship. In contrast, Urang Dagang is a group of people who come to Minangkabau land with the aim of military invasion, trade, economic activities, religious activities, and other types of occupation. This group and its descendants have no right to have a collective inheritance, let alone to devolution of collective heritage to relatives in matrilineal relatives.

Tambo Minangkabau as a work of historiography, ensures the rules, even with the exposure that seems simple, natural, underestimated because of the ancient Tambo Minangkabau language media. However, it turns out that the presence of a text that appears natural is in fact, an ideological construction. Various codes have directed people to a system of world order, including the order in possession of the material property as well as even non-material, in the form of customary titles. Urang Dagang will not be altogether a relative of Urang Asa even if there is an opportunity for them through tradition to claim to be the niece of a Mamak from a specific tribe in Minangkabau. Both do not share the same rights and responsibilities in Minangkabau society.

\section{Acknowledgement}

I would like to thank DRPM who have given this research grant with Decree No. 034/SP2H/LT/DRPM/2020 and Contract Number T/61/UN.16.17. PT. 01.03/PTM-SosialHumniora/2020.

\section{References}

[1] J. Culler, The Pursuit of Signs: Semiotics, Literature, Deconstruction, vol. 40, no. 3. 1982.

[2] T. Kato, "Change and Continuity in the Minangkabau," 1978.

[3] E. Djamaris, Tambo Minangkabau: Suntingan Teks Disertai Analisis Struktur. Jakarta: Yayasan Lontar, 1989.

[4] S. Rosa, "Deceptive Strategies in Literature: The Meaning of Folded Story," J. Hum., vol. 31, no. 3, p. 302, 2019, DOI: 10.22146/jh.43880.

[5] R. Barthes, Elements of Semiology, no. 6. New York: Hill and Wang, 1986.

[6] R. Barthes, S/Z, English tr. Britain: Brazil Blackwell, 1974. 
[7] S. Mason and M. Bernstein, "On links: Exercises in style," HT 2019 - Proc. 30th ACM Conf. Hypertext Soc. Media, pp. 103-110, 2019, DOI: 10.1145/3342220.3343665.

[8] D. F. Sawyer, D. S. Hunter, D. B. Little, and D. G. Elliott, "The Impact of Lexia Reading Program on Early Childhood Literacy: A Case Study of Kindergarten Students," Int. J. Contemp. Res. Rev., vol. 9, no. 02, pp. 20296-20309, 2018, DOI: 10.15520/ijcrr/2018/9/02/431.

[9] A. C. K. Cheung and R. E. Slavin, "Effects of educational technology applications on reading outcomes for struggling readers: A best-evidence synthesis," Read. Res. Q., vol. 48, no. 3, pp. $277-$ 299, 2013, DOI: $10.1002 /$ rrq.50.

[10] D. B. Sango, Tambo Minangkabau. Payakumbuh: Limbago, 1959.

[11] N. Lustyantie, "Pendekatan Semiotika Model Roland Barthes dalam Karya Sastra Prancis," Semin. Nas. FIB UI, pp. 1-15, 2012.

[12] A. Leak, Barthes Mythologies. Grant \& Cutler Ltd, 1994. 